\title{
Yield of Boro Rice as Influenced by Integrated Nutrient Management in Lateritic Soils of West Bengal, India
}

\author{
Monisankar Bera, Goutam K. Ghosh", Suchhanda Mondal, \\ Pabitra K. Biswas and Manik C. Kundu
}
Department of Soil Science and Agricultural Chemistry, Palli Siksha Bhavana, Institute of Agriculture, Visva-Bharati, Sriniketan 731236, West Bengal, India

*Corresponding author

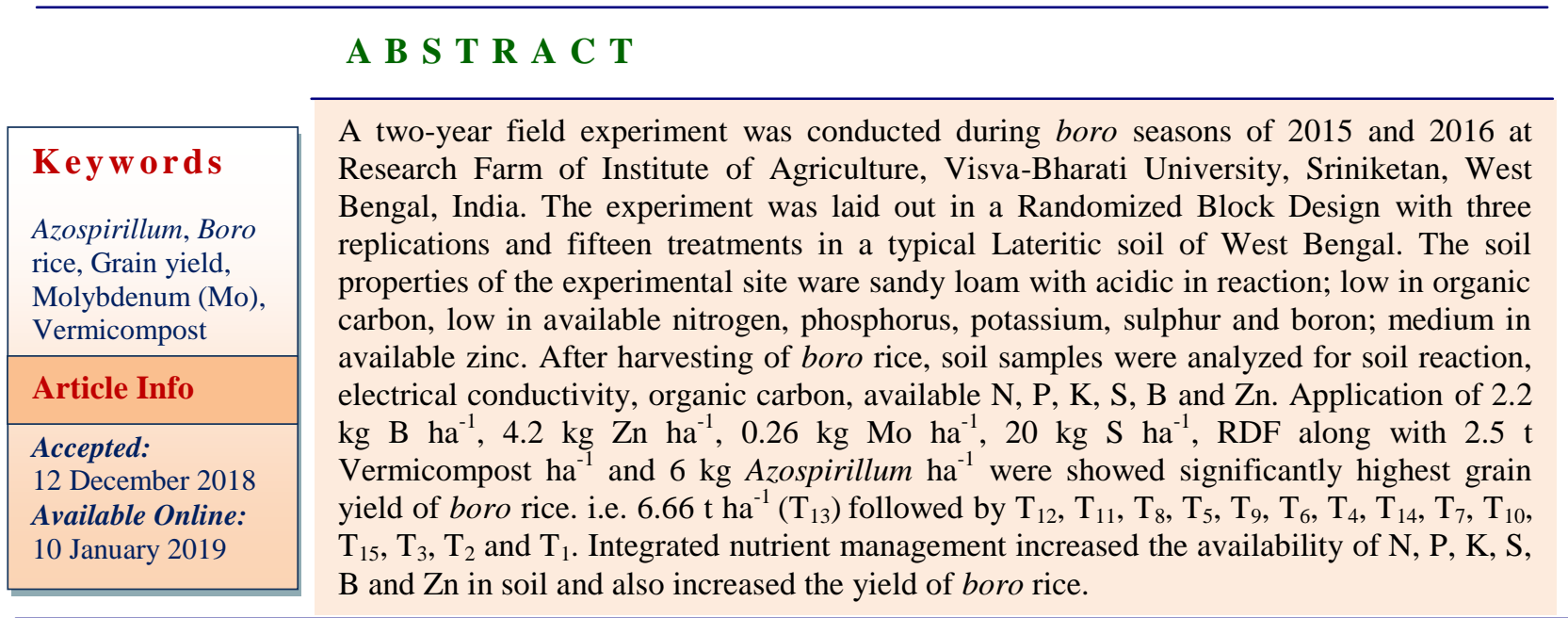

\section{Introduction}

The major challenges in 21st century are food security, environmental quality and soil health. Rice is an important staple food crop of the tropical world. Over 90 per cent of the world's rice is produced and consumed in the Asia-Pacific Region (FAO, 2017). In 2018, more than 48 million tonnes of rice will be consumed worldwide, according to the USDA. Rice is currently grown in over a hundred countries that produce more than 752 million tons of paddy rice annually (Fig. 5). Overall rice production in Asia is expected to reach 686.1 million tonnes (FAO 2017) and in India it is estimated at 109.7 Million tons (IGC 2018). Among rice suppliers, India is expected to remain the world's top exporter (Fig. 4).

The world's population will hit 9 billion by 2050 (Dubois 2011). In order to feed this escalating population, the world requires a global revolution and cereal production potential must increase. Rice (Oryza sativa L.) is the staple food of more than $60 \%$ of the world's population and provides up to $50 \%$ of the dietary caloric supply for millions living 
in poverty (Muthayya et al., 2014). Rice annual deficit is estimated to increase from $400000 \mathrm{t}$ in 2016 to $800000 \mathrm{t}$ by 2030 (Thirze 2016). According to a comprehensive study conducted by the Food and Agricultural Policy Research Institute, demand for rice is expected to continue to increase in coming years, at least up until 2035 (Cago, 2017). Sustained by growing food use, world rice utilization is expected to expand by $1.0 \%$ in 2018/19 to 509.5 million tonnes (Fig. 6).

Indian soils were more or less deficiency of primary nutrients (Nitrogen, Phosphorous and Potassium). Besides the three primary nutrients, deficiency of Sulphur and micro nutrients like Zinc and Boron in many of States, and of Iron, Manganese and Molybdenum in some States, has become a limiting factor in increasing food productivity.

Red and lateritic soils represent 70 million ha of the land area in India (Sehgal, 1998). These soils are usually less productive soil due to coarse in soil texture, low water holding capacity, acidic in soil reaction, poor availability of $\mathrm{N}, \mathrm{P}, \mathrm{K}, \mathrm{S}$ and $\mathrm{B}$ also, medium to high in soil available zinc, low soil organic $\mathrm{C}$ percentage, and both excessive and inadequate levels of several secondary and trace elements. A large area under this soil group in West Bengal remains in fallow or is mono- cultivated with kharif rice. However, productivity of rice in these soils is low due to multi-nutrient deficiencies and other allied problems.

Fertilizer use was started in the country with the start of planning process in early fifties. However, only negligible quantities were consumed during initial years. Increased agricultural production worldwide, particularly in the developing world with a remarkable success was achieved during Green Revolution or Third Agricultural
Revolution beginning most markedly in the late 1960s with the adoption of high yielding variety of seeds (specially wheat) and rice's, in association with chemical fertilizers and agro-chemicals, and with controlled watersupply and credit to the farmers, brought about increased food production. By 2010-11, production of food grain had increased 4.8 times.

After nitrogen (N), phosphorus (P) and potassium $(\mathrm{K})$, widespread zinc $(\mathrm{Zn})$ deficiency has been found responsible for yield reduction in rice (Fageria et al., 2002 and Quijano-Guerta et al., 2002). The increased in yield might be due to positive effect of zinc on yield attributes as it plays an important role in metabolic process (Shanti et al., 2008 and Ahmed et al., 2013). Zinc increased significantly with increasing $\mathrm{Zn}$ rate in the soil (Fageria et al., 2011). Boron has a role in carbohydrate, fat and protein metabolism and formation of compounds with sugar and organic acids. Boron deficiency disturbs the meristamatic action of the growing point and affects the pollen formation resulting immature grains (Yamasaki, 1964). Each increment in sulphur level significantly improved sulphur content in rice shoot at all the crop growth stages as well as in grain and straw at harvest (Chandel et al., 2003). The sulphur content in rice shoot was initially higher at early growth stages while it decreased with the advancement in age of crop and reached its minimum level at crop harvest. It may be simply due to dilution effect (Singh et al., 1993). In acid soils Mo is present but relatively unavailable to plants. Seeds used to plant a crop may contain sufficient Mo to prevent subsequent Mo deficiency in the crop even when they are sown on Mo deficient soils (Jongruaysup et al., 1997).

A traditional method of rice cultivation without organic sources has a significant 
impact on soil quality as well as productivity. Therefore, integrated nutrient management hopefully could contribute to improve the soil health and maximization of crop yield as well as adoption of boro rice. This is a very useful option in lateritic zone where soil is low in organic carbon, poor in fertility and highly degraded. In this regions local farmers use only inorganic fertilizers for accelerating yield potential. Judicious use of specific N-P$\mathrm{K}$ fertilizers fails to sustain soil health and productivity but combined use of N-P-K fertilizers along with micronutrients, vermicompost and bio-fertilizers could produce higher yields and similarly improve the soil fertility. With this view, the present study was conducted.

\section{Materials and Methods}

A field experiment was carried out during boro season of 2015 and 2016 in Agricultural Research Farm of the Institute of agriculture, Visva-Bharati, Sriniketan, Birbhum. The experimental site was situated at $23^{\circ} 29^{\prime} \mathrm{N}$ latitude and $87^{\circ} 42^{\prime} \mathrm{E}$ longitude with an average altitude of $58.9 \mathrm{~m}$ above the mean sea level under sub humid semi-arid region of West Bengal. The soil properties of the experimental site were sandy loam in texture, acidic in soil reaction ( $\mathrm{pH} 4.9)$ and low in organic $\mathrm{C}(0.28 \%)$. The soil was low in available $\mathrm{N}\left(175 \mathrm{~kg} \mathrm{ha}^{-1}\right), \mathrm{P}\left(12 \mathrm{~kg} \mathrm{ha}^{-1}\right), \mathrm{K}$ $\left(85 \mathrm{~kg} \mathrm{ha}^{-1}\right), \mathrm{S}\left(6.2 \mathrm{~kg} \mathrm{ha}^{-1}\right), \mathrm{B}\left(0.4 \mathrm{mg} \mathrm{kg}^{-1}\right)$ and medium in available $\mathrm{Zn}\left(2.13 \mathrm{mg} \mathrm{kg}^{-1}\right)$. The detailed treatments combination tested in the present experiment are given in table 1 .

The $\mathrm{pH}$ of the soils were determined by using soil water suspension (1:2.5) following the method of Jackson (1973), organic carbon (OC) was determined by wet digestion method of Walkey and Black (1934) as described by Jackson (1973), available N content of the soils were estimated by alkaline potassium permanganate method of Subbaiah and Asija (1956), available P content of soil samples were estimated by Bray and Kurtz (1945), available $\mathrm{K}$ of soil samples were determined using $1 \mathrm{~N} \mathrm{NH}_{4} \mathrm{OAc}(1: 5:$ : soil: neutral normal ammonium acetate) extract of the soil using flame photometer (Jackson 1973), available $\mathrm{S}$ in the soils were extracted using $0.15 \% \mathrm{CaCl}_{2}$ solution by Williams and Steinberg (1959) and soil extract was determined using turbidimetric method of Chesnin and Yien (1951), available B content of the soils were estimated by hot water extractable method (Page et al., 1982) and DTPA extractable available $\mathrm{Zn}$ of soils were assessed by the procedure of Lindsay and Norvell (1978). The collected data were analysed statically and the mean values were compared by DMRT $(p \leq 0.05)$ by using the SPSS (IBM SPSS Statistics, Version 25) software package.

\section{Results and Discussion}

The result sowed that grain yield (pooled) of boro rice increased significantly from $4.93 \mathrm{t}$ $\mathrm{ha}^{-1}\left(\mathrm{~T}_{1}\right)$ to $6.66 \mathrm{t} \mathrm{ha}^{-1}\left(\mathrm{~T}_{13}\right)$ and similar result observed in the year of 2015 and 2016 (Fig. $1)$. The increasing order of yield of boro rice ( $\mathrm{h} \mathrm{ha}^{-1}$ ) in as follows: $\mathrm{T}_{13}>$ $\mathrm{T}_{12}>\mathrm{T}_{11}>\mathrm{T}_{8}>\mathrm{T}_{5}>\mathrm{T}_{9}>\mathrm{T}_{6}>\mathrm{T}_{4}>\mathrm{T}_{14}>\mathrm{T}_{7}>\mathrm{T}_{10}>\mathrm{T}_{15}>$ $\mathrm{T}_{3}>\mathrm{T}_{2}>\mathrm{T}_{1}$ (Table 1).

The DMRT of grain yield (pooled) of boro rice is also provided (Table 2) five subset among fifteen different treatments, showed that yield of the treatments listed in the same subset are not significantly different. So, subset $\mathrm{e}$, which consists $\mathrm{T}_{11}, \mathrm{~T}_{12}, \mathrm{~T}_{13}$ is significantly different from subset a $\left(\mathrm{T}_{1}\right)$ as well as others subset i.e. b, c and d. As a result from Table 2, application of all nutrients (macro and micro), organic manure and bio-fertilizers in an integrated manner obtained significantly highest yield (pooled) of boro rice in $\mathrm{T}_{13}$ and this was the best treatment over control. Harmonic mean 
sample size $=6.00$ and a significant result has been found $\mathrm{F}(14,56)=10.88, P<0.001$. The result is (highly) significant.

Application of $2.2 \mathrm{~kg} \mathrm{~B} \mathrm{ha}^{-1}, 4.2 \mathrm{~kg} \mathrm{Zn} \mathrm{ha}^{-1}$, $0.26 \mathrm{~kg} \mathrm{Mo} \mathrm{ha}^{-1}, 20 \mathrm{~kg} \mathrm{~S}^{-1}$, RDF along with $2.5 \mathrm{t}$ Vermicompost $\mathrm{ha}^{-1}$ and $6 \mathrm{~kg}$ Azospirillum ha $^{-1}$ were obtained significantly higher straw yield (pooled) of boro rice i.e. $7.05 \mathrm{t} \mathrm{ha}^{-1}$ than control $\left(5.50 \mathrm{t} \mathrm{ha}^{-1}\right)$ and more or less similar results obtained in both year (Fig. 2) and biological yield (pooled) of boro rice increased significantly from $10.43 \mathrm{t} \mathrm{ha}^{-1}$ $\left(\mathrm{T}_{1}\right)$ to $13.71 \mathrm{t} \mathrm{ha}^{-1}\left(\mathrm{~T}_{13}\right)$ i.e. proportional with the year of 2015 and 2016 (Fig. 3). The maximum rice yield increased with combined application of sulphur and zinc over control (Mondal et al., 2004 and Singh et al., 2011).

It was observed that soil $\mathrm{pH}$ (pooled) ranges from $4.91\left(\mathrm{~T}_{1}\right)$ to $5.26\left(\mathrm{~T}_{4}\right.$ and $\left.\mathrm{T}_{7}\right)$. The pooled results (Table 3) showed that the soil $\mathrm{pH}$ under boro rice was positively increased, of all the treatments of INM, over control in a lateritic soil, indicating the application of fertilizers in an integrated manner to soils which not only decreased the soil acidity but increase the rate of nutrient availability. Wardle (1992) showed that the soil $\mathrm{pH}$ is probably at least as important as soil $\mathrm{N}$ and $\mathrm{C}$ concentrations in influencing the size of soil microbial biomass.

The effect of different treatments on soil electrical conductivity (EC) by boro rice crop in INM showed (Table 3) that the soil EC (pooled) ranged from $0.08 \mathrm{dS} \mathrm{m}^{-1}$ to $0.15 \mathrm{dS}$ $\mathrm{m}^{-1}$. According to Bruckner (2012), lower soil $\mathrm{pH}$ indicates larger number of hydrogen ions in the soil.

Hydrogen ions can appear in varying amount in the soil environment which can affect the level of electrical conductivity. Higher amount of hydrogen ions in the soil will show a higher rate of electrical conductivity. Hence, low soil $\mathrm{pH}$ due to large number of hydrogen ions in the soil may encourage soil electrical conductivity.

Result (pooled) of soil organic carbon (OC) was recorded after harvesting the boro rice for (Table 3). The changes in the amount of soil OC also showed similar trend. Pooled data (Table 3) showed that percentage OC in soil was significantly highest in the treatment $\mathrm{T}_{11}$, where $2.5 \mathrm{t} \mathrm{ha}^{-1}$ vermicompost was used along with $\mathrm{T}_{10}(\mathrm{~N}, \mathrm{P}, \mathrm{K}, \mathrm{S}, \mathrm{Zn}, \mathrm{B}$ and $\mathrm{Mo})$ and highest OC was $0.36 \%$ and lowest was 0.29\%. Mohd Aizat et al., (2014) observed that, in acidic soil condition, soil microbial biomass $\mathrm{C}$ and biomass $\mathrm{N}$ were related positively in the form of power function with soil $\mathrm{pH}$ and negatively with soil electrical conductivity.

Soil available nitrogen (pooled) in $\mathrm{T}_{15}$ was highest i.e. $294.79 \mathrm{~kg} \mathrm{ha}^{-1}$ after harvest of boro rice (Table 3) where Azospirillum used as a biofertilizer along with RDF (N:P:K::80:40:40). The effects of different treatments on soil available phosphorus of boro rice are presented in Table 3. Result revealed that the soil available phosphorus (pooled) was highest in $\mathrm{T}_{12}(\mathrm{~N}, \mathrm{P}, \mathrm{K}, \mathrm{S}, \mathrm{Zn}, \mathrm{B}$, Mo, $\mathrm{VC}$ and Azotobacter) i.e. $23.83 \mathrm{~kg} \mathrm{ha}^{-1}$ and lowest $\left(15.35 \mathrm{~kg} \mathrm{ha}^{-1}\right)$ in control $\left(\mathrm{T}_{1}\right)$ plot, which is without fertilizers. Pooled data (Table 3) showed that the available potassium content in soil after harvest of boro rice ranges from $56.74 \mathrm{~kg} \mathrm{ha}^{-1}$ to $78.20 \mathrm{~kg} \mathrm{ha}^{-1}$ and highest in $\mathrm{T}_{9}$ with application of $\mathrm{RDF}+\mathrm{B}$ $\left(2.2 \mathrm{~kg} \mathrm{ha}^{-1}\right)+\mathrm{Zn}\left(4.2 \mathrm{~kg} \mathrm{ha}^{-1}\right)+$ Mo $(0.26 \mathrm{~kg}$ $\mathrm{ha}^{-1}$ ). Biofertilizer helps in nitrogen fixation, synthesize and secrete many amino acids which influence seed germination, plant growth and yield (Sardana 1997).

The highest available sulphur (pooled) was $26.94 \mathrm{~kg} \mathrm{ha}^{-1}$ and lowest was $13.07 \mathrm{~kg} \mathrm{ha}^{-1}$ (Table 3). The highest value of available $\mathrm{S}$ was recorded in the plots receiving all 
nutrients used in INM except Azospirillum. The sources of S viz. Gypsum, Magnesium sulphate and Single superphosphate and levels of sulphur $\left(0,20,40,60\right.$ and $\left.80 \mathrm{~kg} \mathrm{~S} \mathrm{ha}^{-1}\right)$ application not only increase the available sulphur status over control, but also over initial soil sulphur status (Bera et al., 2015).

Table.1 Treatment details of the experiment

\begin{tabular}{|c|l|}
\hline \multicolumn{2}{|c|}{$\quad$ Inorganic/Organic/Bio-inoculant input combinations } \\
\hline Treatments & \multicolumn{2}{|c|}{} \\
\hline $\mathbf{T}_{\mathbf{1}}$ & Control \\
\hline $\mathbf{T}_{\mathbf{2}}$ & $\mathrm{RDF}^{*}$ \\
\hline $\mathbf{T}_{\mathbf{3}}$ & $\mathrm{RDF}^{*}+\mathrm{B}_{2.2}$ \\
\hline $\mathbf{T}_{\mathbf{4}}$ & $\mathrm{RDF}^{*}+\mathrm{Zn}_{4.2}$ \\
\hline $\mathbf{T}_{\mathbf{5}}$ & $\mathrm{RDF}^{*}+\mathrm{S}_{20}$ \\
\hline $\mathbf{T}_{\mathbf{6}}$ & $\mathrm{RDF}^{*}+\mathrm{Mo}_{0.26}$ \\
\hline $\mathbf{T}_{\mathbf{7}}$ & $\mathrm{RDF}^{*}+\mathrm{Vermicompost}_{2.5}{ }^{* *}$ \\
\hline $\mathbf{T}_{\mathbf{8}}$ & $\mathrm{RDF}^{*}+\mathrm{B}_{2.2}+\mathrm{Zn}_{4.2}$ \\
\hline $\mathbf{T}_{\mathbf{9}}$ & $\mathrm{RDF}^{*}+\mathrm{B}_{2.2}+\mathrm{Zn}_{4.2}+\mathrm{Mo}_{0.26}$ \\
\hline $\mathbf{T}_{\mathbf{1 0}}$ & $\mathrm{RDF}^{*}+\mathrm{B}_{2.2}+\mathrm{Zn}_{4.2}+\mathrm{Mo}_{0.26}+\mathrm{S}_{20}$ \\
\hline $\mathbf{T}_{\mathbf{1 1}}$ & $\mathrm{RDF}^{*}+\mathrm{B}_{2.2}+\mathrm{Zn}_{4.2}+\mathrm{Mo}_{0.26}+\mathrm{S}_{20}+$ Vermicompost $_{2.5}{ }^{* *}$ \\
\hline $\mathbf{T}_{\mathbf{1 2}}$ & $\mathrm{RDF}^{*}+\mathrm{B}_{2.2}+\mathrm{Zn}_{4.2}+\mathrm{Mo}_{0.26}+\mathrm{S}_{20}+$ Vermicompost $_{2.5}{ }^{* *}+$ Azotobacter $_{6}$ \\
\hline $\mathbf{T}_{\mathbf{1 3}}$ & $\mathrm{RDF}^{*}+\mathrm{B}_{2.2}+\mathrm{Zn}_{4.2}+\mathrm{Mo}_{0.26}+\mathrm{S}_{20}+$ Vermicompost $_{2.5}{ }^{* *}+$ Azospirillum $_{6}$ \\
\hline $\mathbf{T}_{\mathbf{1 4}}$ & $\mathrm{RDF}^{*}+$ Azotobacter $_{6}$ \\
\hline $\mathbf{T}_{\mathbf{1 5}}$ & $\mathrm{RDF}^{*}+$ Azospirillum $_{6}$ \\
\hline & \\
\hline
\end{tabular}

Table.2 Effect of integrated nutrient management on grain, straw and biological yield of boro rice in a lateritic soil of West Bengal (pooled)

\begin{tabular}{|c|c|c|c|}
\hline Treatment & Grain $\left(t_{\text {ha }}^{-1}\right)$ & Straw $\left(\mathrm{t} \mathrm{ha}^{-1}\right)$ & Biological $\left(\mathrm{t} \mathrm{ha}^{-1}\right)$ \\
\hline $\mathrm{T}_{1}$ & $4.93^{\mathrm{e}}$ & $5.50^{\mathrm{d}}$ & $10.43^{\mathrm{e}}$ \\
\hline $\mathbf{T}_{2}$ & $6.01^{\mathrm{d}}$ & $6.51^{c}$ & $12.52^{\mathrm{d}}$ \\
\hline $\mathbf{T}_{3}$ & $6.08^{\mathrm{cd}}$ & $6.59^{\mathrm{bc}}$ & $12.67^{\text {cd }}$ \\
\hline $\mathbf{T}_{4}$ & $6.22^{\mathrm{bcd}}$ & $6.58^{c}$ & $12.80^{\text {cd }}$ \\
\hline $\mathbf{T}_{5}$ & $6.26^{\mathrm{bcd}}$ & $6.59^{\mathrm{bc}}$ & $12.86^{\mathrm{cd}}$ \\
\hline$T_{6}$ & $6.24^{\mathrm{bcd}}$ & $6.78^{\mathrm{abc}}$ & $13.02^{\mathrm{bcd}}$ \\
\hline $\mathbf{T}_{7}$ & $6.14^{\mathrm{cd}}$ & $6.60^{\mathrm{bc}}$ & $12.74^{\text {cd }}$ \\
\hline $\mathbf{T}_{8}$ & $6.29^{\mathrm{bcd}}$ & $6.72^{\mathrm{abc}}$ & $13.01^{\text {bed }}$ \\
\hline $\mathbf{T}_{9}$ & $6.25^{\mathrm{bcd}}$ & $6.62^{\mathrm{bc}}$ & $12.88^{\mathrm{cd}}$ \\
\hline$T_{10}$ & $6.13^{\mathrm{cd}}$ & $6.70^{\mathrm{bc}}$ & $12.83^{\mathrm{cd}}$ \\
\hline$T_{11}$ & $6.41^{a b c}$ & $6.82^{\mathrm{abc}}$ & $13.24^{\mathrm{abc}}$ \\
\hline$T_{12}$ & $6.59^{\mathrm{ab}}$ & $6.95^{\mathrm{bc}}$ & $13.54^{\mathrm{ab}}$ \\
\hline$T_{13}$ & $6.66^{\mathrm{a}}$ & $7.05^{\mathrm{a}}$ & $13.71^{\mathrm{a}}$ \\
\hline $\mathbf{T}_{14}$ & $6.20^{\mathrm{cd}}$ & $6.58^{\mathrm{c}}$ & $12.78^{\mathrm{cd}}$ \\
\hline $\mathbf{T}_{15}$ & $6.11^{\mathrm{cd}}$ & $6.52^{c}$ & $12.63^{\mathrm{cd}}$ \\
\hline SEm \pm & 0.17 & 0.16 & 0.29 \\
\hline C.D. at $5 \%$ & 0.33 & 0.31 & 0.58 \\
\hline C.V. (\%) & 4.67 & 4.06 & 3.9 \\
\hline
\end{tabular}


Table.3 Effect of integrated nutrient management on soil $\mathrm{pH}, \mathrm{EC}, \mathrm{OC}$ and available $\mathrm{N}, \mathrm{P}, \mathrm{K}, \mathrm{S}, \mathrm{Zn}$ and $\mathrm{B}$ of boro rice in a lateritic soil of West Bengal (pooled)

\begin{tabular}{|c|c|c|c|c|c|c|c|c|c|}
\hline Treatment & $\mathrm{pH}(1: 2.5)$ & 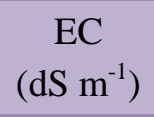 & $\begin{array}{l}\text { OC } \\
(\%)\end{array}$ & $\begin{array}{c}\mathrm{N} \\
\left(\mathrm{kg} \mathrm{ha}^{-1}\right)\end{array}$ & $\begin{array}{c}\mathrm{P} \\
\left(\mathrm{kg} \mathrm{ha}^{-1}\right)\end{array}$ & $\begin{array}{c}\mathrm{K} \\
\left(\mathrm{kg} \mathrm{ha}^{-1}\right)\end{array}$ & $\begin{array}{c}\mathrm{S} \\
\left(\mathrm{kg} \mathrm{ha}^{-1}\right)\end{array}$ & $\begin{array}{c}\mathrm{Zn} \\
\left(\mathrm{mg} \mathrm{kg}^{-1}\right)\end{array}$ & $\begin{array}{c}\text { B } \\
\left(\mathrm{mg} \mathrm{kg}^{-1}\right)\end{array}$ \\
\hline $\mathbf{T}_{1}$ & 4.91 & 0.15 & 0.29 & 263.42 & 15.35 & 66.09 & 13.07 & 2.10 & 0.22 \\
\hline $\mathbf{T}_{2}$ & 5.11 & 0.13 & 0.32 & 284.33 & 20.32 & 56.74 & 15.56 & 2.44 & 0.32 \\
\hline $\mathbf{T}_{3}$ & 5.12 & 0.10 & 0.29 & 238.76 & 17.86 & 59.07 & 17.15 & 2.41 & 0.42 \\
\hline $\mathbf{T}_{4}$ & 5.26 & 0.09 & 0.31 & 252.97 & 21.81 & 63.51 & 20.77 & 3.13 & 0.33 \\
\hline $\mathbf{T}_{5}$ & 5.18 & 0.08 & 0.30 & 238.34 & 17.65 & 70.69 & 23.29 & 2.35 & 0.32 \\
\hline$T_{6}$ & 4.94 & 0.13 & 0.35 & 267.61 & 18.44 & 63.40 & 18.69 & 2.39 & 0.31 \\
\hline $\mathbf{T}_{7}$ & 5.26 & 0.09 & 0.33 & 261.33 & 17.47 & 58.55 & 20.45 & 2.71 & 0.34 \\
\hline $\mathbf{T}_{8}$ & 5.19 & 0.10 & 0.31 & 242.52 & 18.69 & 67.41 & 23.04 & 3.15 & 0.33 \\
\hline $\mathbf{T}_{9}$ & 5.15 & 0.12 & 0.35 & 269.70 & 17.17 & 78.20 & 21.56 & 2.68 & 0.32 \\
\hline $\mathbf{T}_{10}$ & 5.12 & 0.14 & 0.34 & 255.06 & 20.35 & 63.25 & 25.74 & 2.79 & 0.32 \\
\hline $\mathbf{T}_{11}$ & 5.04 & 0.14 & 0.36 & 278.06 & 21.95 & 76.73 & 25.57 & 3.12 & 0.36 \\
\hline$T_{12}$ & 5.14 & 0.13 & 0.32 & 259.24 & 23.83 & 68.58 & 26.94 & 3.02 & 0.35 \\
\hline $\mathbf{T}_{13}$ & 5.10 & 0.11 & 0.29 & 267.19 & 18.38 & 60.98 & 25.00 & 2.97 & 0.33 \\
\hline $\mathbf{T}_{14}$ & 4.98 & 0.13 & 0.32 & 284.33 & 20.34 & 57.31 & 18.89 & 2.31 & 0.28 \\
\hline $\mathbf{T}_{15}$ & 5.08 & 0.09 & 0.34 & 294.79 & 17.79 & 71.86 & 18.69 & 2.36 & 0.27 \\
\hline$S E m \pm$ & 0.09 & 0.02 & 0.03 & 22.91 & 2.03 & 5.8 & 0.92 & 0.20 & 0.02 \\
\hline C.D. at $5 \%$ & 0.18 & NS & NS & NS & 4.06 & 11.63 & 1.84 & 0.40 & 0.04 \\
\hline C.V. (\%) & 3.09 & 35.80 & 17.07 & 15.04 & 18.34 & 15.35 & 7.58 & 13.13 & 9.84 \\
\hline
\end{tabular}



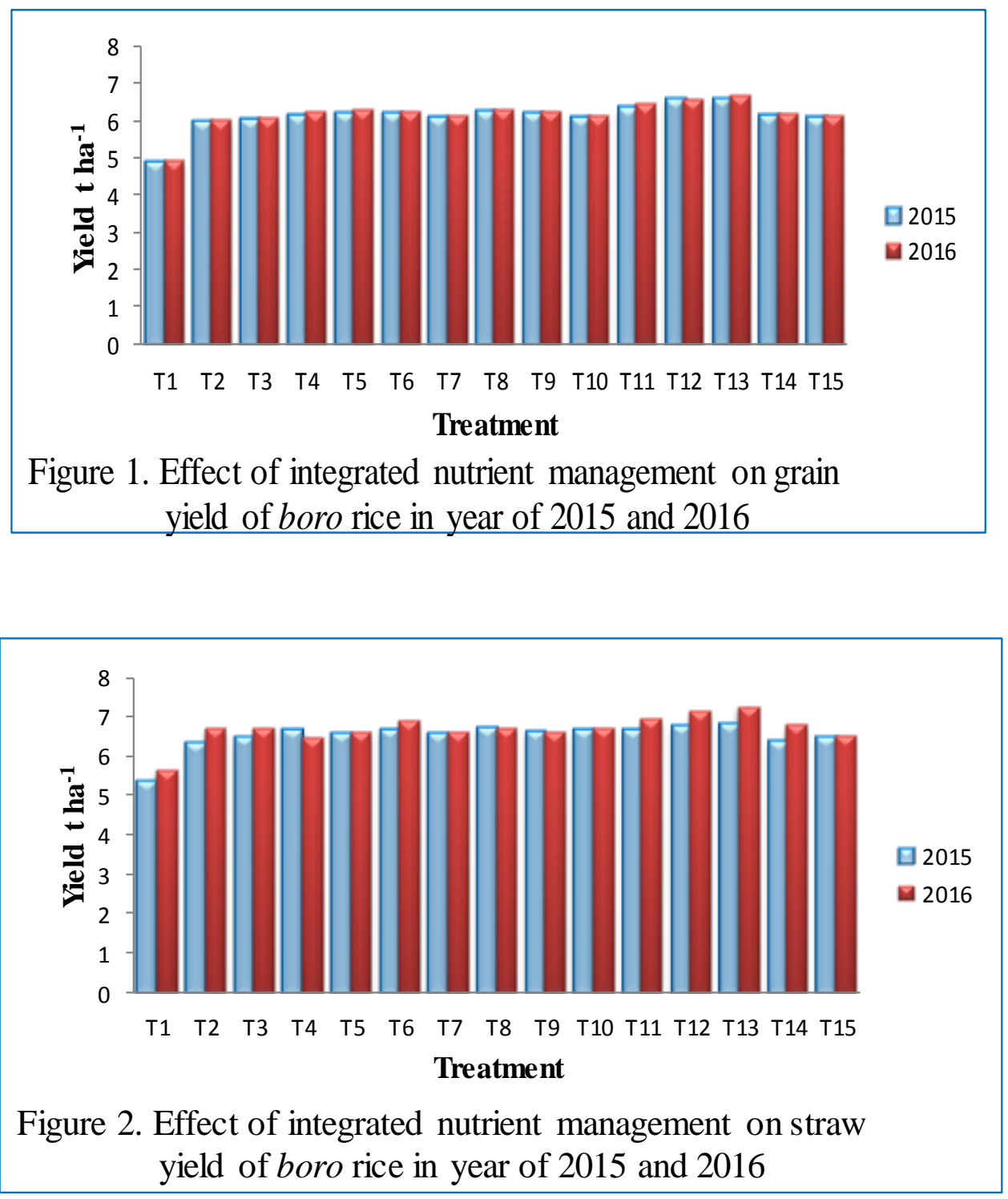
Int.J.Curr.Microbiol.App.Sci (2019) 8(1): 1743-1754

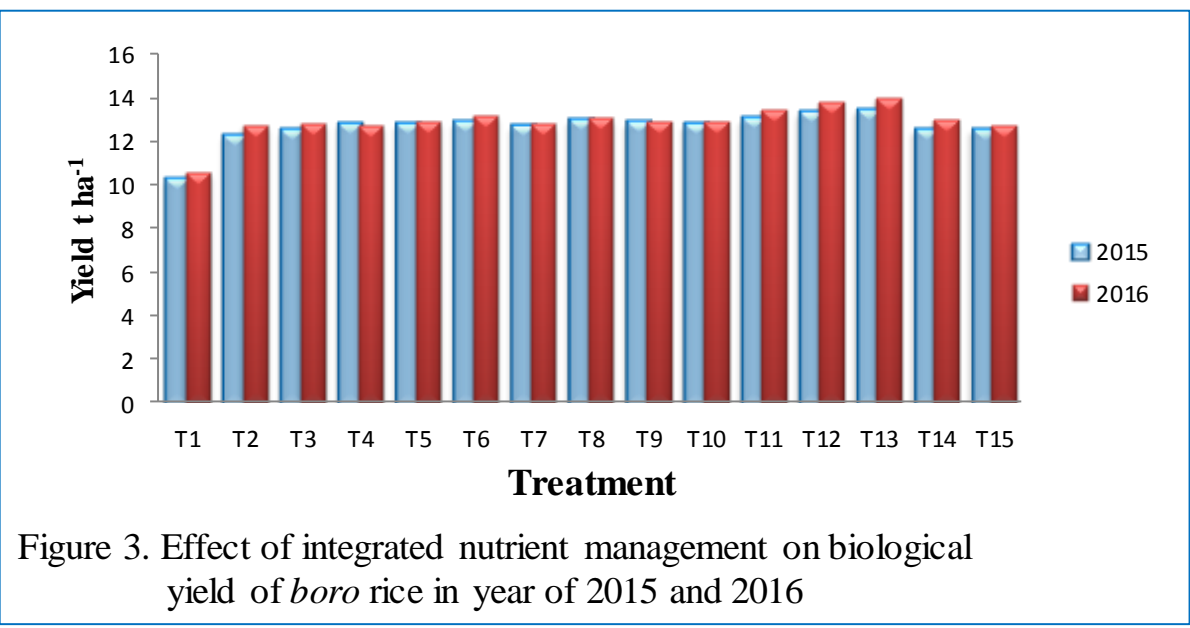

Fig.4 Major rice exporters and importers (FAO 2018)

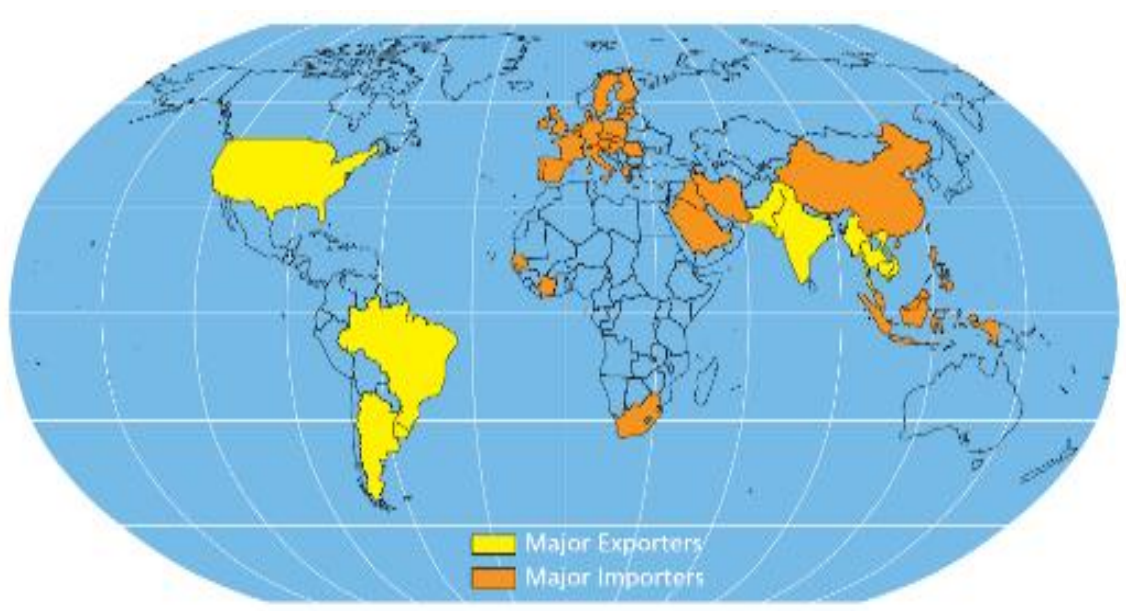


Fig.5 Global paddy production area (FAO 2018)

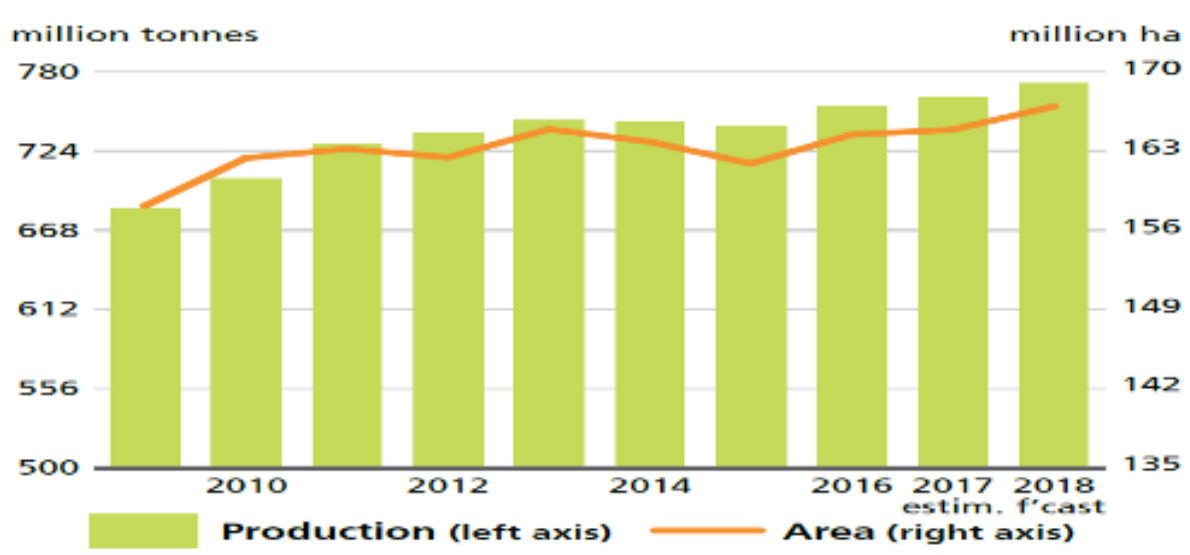

Fig.6 Global rice production utilization and stocks (FAO 2018)

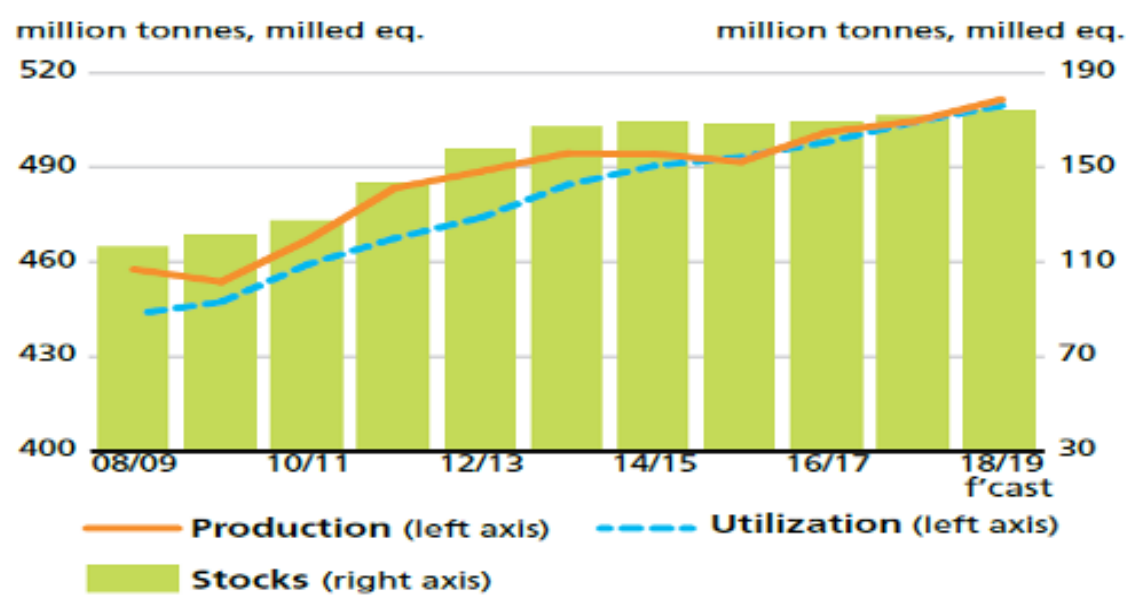


Available zinc content (pooled) in the soil after harvest the boro rice ranged from 2.10 $\mathrm{mg} \mathrm{kg}{ }^{-1}$ in $\mathrm{T}_{1}$ to $3.15 \mathrm{mg} \mathrm{kg}^{-1}$ in $\mathrm{T}_{8}$. Available zinc significantly increased in $\mathrm{T}_{8}, \mathrm{~T}_{4}, \mathrm{~T}_{11}$ and $\mathrm{T}_{12}$ where content was $\mathrm{Zn}>3 \mathrm{mg} \mathrm{kg}$ compared to other treatments. Effect of integrated nutrient management on the soil available boron revealed that the highest available boron content $\left(0.42 \mathrm{mg} \mathrm{kg}^{-1}\right)$ with application of RDF and boron@ $2.2 \mathrm{~kg} \mathrm{ha}^{-1}$ along with $\mathrm{RDF}\left(\mathrm{T}_{3}\right)$. Addition of $\mathrm{S}+\mathrm{Zn}+\mathrm{B}$ in balanced fertilization schedule increased $\mathrm{N}$, $P$ and $K$ utilization efficiency which highlights the role of micronutrients in increasing macronutrient use efficiency (Shukla, 2011).

In conclusion the present study was concluded that the soil health has been improved through INM incorporated with organic, inorganic and bio-inoculant as compared to inorganic application. It is the best approach among other practices of rice cultivation to sustain the soil health through INM, which will increase the availability of $\mathrm{N}, \mathrm{P}, \mathrm{K}, \mathrm{S}, \mathrm{B}$ and $\mathrm{Zn}$ in soil and also increases the yield. So, INM practices can be advocated to improve the soil health and socio-economic level of farmers. INM can also be used as part of the global strategy to ensure food security and protect the environment.

\section{References}

Ahmad, I., Akhtar, M. J., Asghar, H. N. and Khalid, M. 2013. Influence of rhizobium applied in combination with micronutrients on mungbean. Pakistan Journal of Life and Social Sciences. 11(1): 53-59.

Bera, M. and Ghosh, G. K. 2015. Efficacy of sulphur sources on green gram (Vigna radiata L.) in red and lateritic soil of West Bengal. International Journal of Plant, Animal and Environmental Sciences. 5(2): 109-116.
Bray, R.H. and Kurtz, L.T. 1945. Determination of total organic and available forms of phosphorus in soil. Soil Science. 59: 39-45.

Bruckner, M. Z. 2012, Water and Soil Characterization- $\mathrm{pH}$ and Electrical Conductivity, Microbial Life Educational Resources. Montana State University Bozeman, 2012.

Cago, L. 2017. 10 Largest Rice Producing Countries. World Atlas. Retrieved 1 January, 2019, from https://www. worldatlas.com/articles/the-countriesproducing-the-most-rice-in-theworld.html.

Chandel, R. S., Singh, K., Singh, A. K., Sudhakar, P. C. and Singh, K. 2003. Effect of sulphur nutrition in rice (Oryza sativa L.) and mustard (Brassica juncea L. Czern and Coss.) grown in sequence. Indian Journal of Plant Physiology. 8(2): 155-159.

Chesnin, L. and Yien, C. H. 1950.Turbidimetric determination of available sulphates. Proc. Soil Sci. Soc. Am. 15: 149-151.

Dubois, O. 2011. The state of the world's land and water resources for food and agriculture: managing systems at risk. Earthscan.

Fageria, N. K., Baligar, V. C. and Clark, R. B. 2002. Micronutrients in crop production. Adv Agron. 77: 185-268.

Food and Agriculture Organization of the United Nations (FAO'S), Food outlook biannual report on global food markets, July 2018.

Food and Agriculture Organization of the United Nations (FAO'S), Rice market monitor, July 2017, VOLUME XX ISSUE No. 2.

International Grains Council. 2018. Grain market report 487, 26- April.

Jackson, M. L. 1973. Soil Chemical Analysis. Prentice Hall of India (Pvt.) Ltd., New Delhi. 
Jongruaysup, S., Dell, B., Bell, R. W., O'hara, G. W. and Bradley, J. S. 1997. Effect of molybdenum and inorganic nitrogen on molybdenum redistribution in black gram (Vigna mungo L. Hepper) with particular reference to seed fill. Annals of botany. 79(1): 67-74.

Lindsay, W.L. and Norvell, W.A. 1978. Development of a DTPA soil test for zinc, iron, manganese and copper. Soil Science Society of America. 42: 421428.

Mohd-Aizat, Sulaiman., Wan, Sulaiman., Azmin, Karam., Daljit, M. K. and Mohamed-Roslan. 2014. The relationship between soil $\mathrm{pH}$ and selected soil properties in 48 years logged-over forest. International Journal of Environmental Sciences.4. 10.6088/ijes.2014040600004.

Mondal, S. S., Ghosh, A., Acharya, D. and Maiti, D. 2004. Production potential and economics of different rainfed rice (Oryza sativa)-based utera cropping systems and its effect on fertility build up of soil. Indian Journal of Agronomy. 49(1): 6-9.

Muthayya, S., Sugimoto, J. D., Montgomery, S. and Maberly, G. F. 2014. An overview of global rice production, supply, trade, and consumption. Annals of the new york Academy of Sciences. 1324(1): 7-14.

Fageria, N. K., Santos, A. B. dos. and Cobucci, T. 2011. Zinc Nutrition of Lowland Rice, Communications in Soil Science and Plant Analysis. 42(14): 1719-1727.

Quijano-Guerta C, Kirk, G. J. D., Portugal. A. M., Bartolome, V. I. and McLaren, G. C. 2002. Tolerance of rice germplasm to zinc deficiency. Field Crops Res. 76: $123-130$.

Sardana, V. 1997. Agronomic Evaluation of Bioinoculants to supplement inorganic fertilizers for sustained crop production- A critical review. Agricultural Research. 18: 69-95.

Sehgal, J. 1998. Red and lateritic soils: an overview. Red and lateritic soils. 1: 310.

Shanti, M., Babu, B. P., Prasad, B. R. and Minhas, P. S. 2008. Effect of zinc on blackgram in rice-blackgram cropping system of coastal saline soils. Legume Res. 31(2): 79-86.

Shukla, Aravind. K. 2011. Micronutrient Research in India: Current Status and Future Strategies, Indian Society of Soil Science. 59: S88-S98.

Singh, A. K., Meena, M. K. and Bharati, R. C. 2011. Sulphur and zinc nutrient management in rice lentil cropping system. In International Conference on Life Science Research for Rural and Agricultural Development, December. CPRS, Patna, Bihar. Pp. 66-67.

Singh, M. Singh, R. P. and Gupta, M. L. 1993. Effect of sulphur on rice. Oyza. 30: 315-317.

Subbaiah, B. V. and Asija, G. L. 1956. A rapid procedure for the estimation of available nitrogen in soil. Current Science. 25: 259-260.

Tai, Y. P. and Young, G. P. 1974. Variation in protein percentage in properties of peanut cotyledons. Crop Sci. 14: 222229.

Tandon, H. L. S. 1991. Sulphur Research and Agril. Production in India, 3rd edition. The Sulphur Institute, Washington D.C. USA. Pp. $140+$ viii.

Thirze, H. 2016. Modelling Grain Surplus/Deficit in Cameroon for 2030. Master degree thesis INES 393. Lund University, Sweden. 59.

Walkley, A. and Black, I. A. 1934. An Examination of Degtjareff Method for Determining Soil Organic Matter and a Proposed Modification of the 
Chromic Acid Titration Method. Soil Science. 37: 29-37.

Wardle, D. A. 1992. A comparative assessment of factors which influence microbial biomass carbon and nitrogen levels in soil. Biological Reviews of the Cambridge Philosophical Society. 67: 321-358.

Williams, C. H. and Steinbergs, A. 1959. Soil sulphur fractions as chemical indices of available sulphur in some Australian soils. Aust. J. Agric. Res. 10: 340-352.

Yamasaki, T. 1964. The role of micro elements, the mineral nutrition of the rice plant, John Hopkins Press, Baltimore, Maryland, U.S.A. Pp. 107122.

\section{How to cite this article:}

Monisankar Bera, Goutam K. Ghosh, Suchhanda Mondal, Pabitra K. Biswas and Manik C. Kundu. 2019. Yield of Boro Rice as Influenced by Integrated Nutrient Management in Lateritic Soils of West Bengal, India. Int.J.Curr.Microbiol.App.Sci. 8(01): 1743-1754.

doi: https://doi.org/10.20546/ijcmas.2019.801.185 